\title{
ENVIRONMENTAL PARAMETERS INFLUENCE IN FODDER AERATION PROCESS FOR CONSERVATION
}

\author{
Ana Zaica, Ancuta Nedelcu, Radu Ciuperca, Alexandru Zaica \\ National Institute of Research-Development for Machines and Installations \\ Designed to Agriculture and Food Industry, Romania \\ zaica_ana@yahoo.com,nedelcuus@yahoo.com, \\ ciupercaradu@yahoo.com, zaica_alexandru@yahoo.com
}

\begin{abstract}
Conservation of fodder plants harvested from meadows and hay fields, in order to provide hay feed for animals, is an important objective for livestock farmers. The rational feeding of animals, especially during the cold season, when they cannot feed, is the determinant factor that highlights their biological potential to produce various, high, constant, year-round and good quality productions. That is why animal husbandry, the health of animals and their productive capacity depend to the greatest extent on the supply of feed / fodder rich in different chemical constituents throughout the year. Harvesting, preparation and conservation of hay is a frequent method for harvesting fodder from grasslands and forage crops, especially from the hill and mountain areas. The greatest losses of nutrients are obtained by traditional drying on the stubble of the hay. These losses are in the case of unfavourable weather (by hay molding) even at 50-60\%, the drying time increasing to over 6-8 days. This paper presents the results of the experimental researches achieved within a new technology for shortening the time from harvesting the fodder plants to obtaining the hay at storage humidity. A pilot ventilation installation with a monitoring and control system for working processes was used to carry out the research. During the experiments, the parameters of the aeration agent were measured: temperature and humidity, as well as fodder mass characteristics: humidity, temperature, drying uniformity. Experiments were conducted in two time periods with different characteristics. The results obtained for two plant varieties were analysed comparatively and the influence of the environmental parameters on the duration of the aeration process has been highlighted.
\end{abstract}

Keywords: aeration, fodder plants, technology, animals.

\section{Introduction}

Within the new concept of sustainable development in animal husbandry, animals in general and ruminants in particular have a special future due to the fact that judicious organization can produce nutritionally balanced and qualitative feed for all species and categories of farm animals.

Under climatic conditions in Romania, the vegetation period lasts for 5-7 months, depending on the altitude. For the rest of the time, animals are given preserved fodder. Besides fodder that is kept as such (feed beet) there are two preservation systems, namely by drying (hay) and by milling (silo) $[1 ; 2]$.

Internationally it distinguishes research, production and providing of a wide range of preparations and additions that compete for the best preserved fodder.

Bovine diet has a specific architecture based on the production of high quality feed and in sufficient quantities to provide balanced rations that will meet the daily requirements of the animal [3].

The feed used in cattle feed can be divided into the following groups: fibrous fodders (hay, coco, straw, etc.); concentrated fodders (cereals, cakes, residues from the milling industry); juicy fodders (silos, roots, chickpeas and bobs); feed additives (premixes) [3].

The primary objective in harvesting, preparing and preserving feed from meadows and forage crops is to produce a final product with a nutritional value as close as possible to the original feed, starting from the premise that it meets the conditions of a very high feed, and in terms of its botanical composition (a balanced mix of grasses with perennial legumes) and the harvesting period [4].

The quality of hay depends on the botanical composition, chemical composition, digestibility of organic substances and consumption, all of which are conditioned by the natural environment, in which the plants, the harvest phase and method, the drying technique and the preservation method have been increased $[5 ; 6]$.

An important role for the high efficiency and efficiency of feed is the system of machines, which, in a relatively short time, corresponding to the optimal harvesting period, has to ensure the harvesting, transportation and storage of a large quantity of vegetal mass with relatively high humidity, with low consumption of labour and minimal material expenses. 


\section{Materials and methods}

The climatic conditions in our country favour the cultivation of a variety of fodder plants, and their modern establishment and maintenance technologies enable them to obtain high yields with superior nutritional qualities. Among the best known and applied technologies for harvesting and preservation of fodder plants, both in the world and in our country, which fully satisfy the requirements of the zoo technical sector [7; 8], are presented in Figure 1.
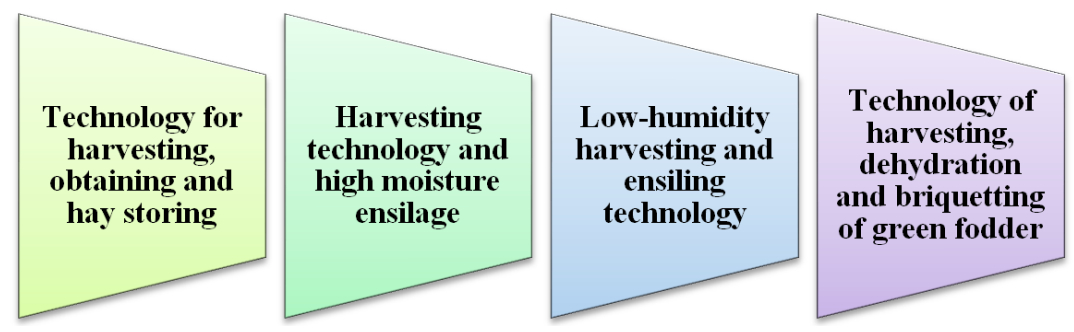

Fig. 1. Methods of harvesting and preserving different types of feed

Concerning the preference criteria or the selection of one of these technologies, production experiments have shown that it cannot be considered to be one or two of these technologies as being the most technically and economically efficient but the simultaneous use of several technologies is envisaged, applying differently depending on a number of factors (type of farm, animal species, climatic conditions, endowment with machines and equipment within the technology, etc.)

Considering the opportunity to study some aspects of the aeration process applied to two varieties of fodder plants in order to maintain their nutritional qualities during their storage and preservation, as part of harvesting technology, obtaining and storage of hay.

A pilot ventilation system (IVF) was used to carry out the research; Figure 2 presents the monitoring and control system of the working processes. Essentially, three factors determine the success of drying: air circulation, temperature control, humidity control.

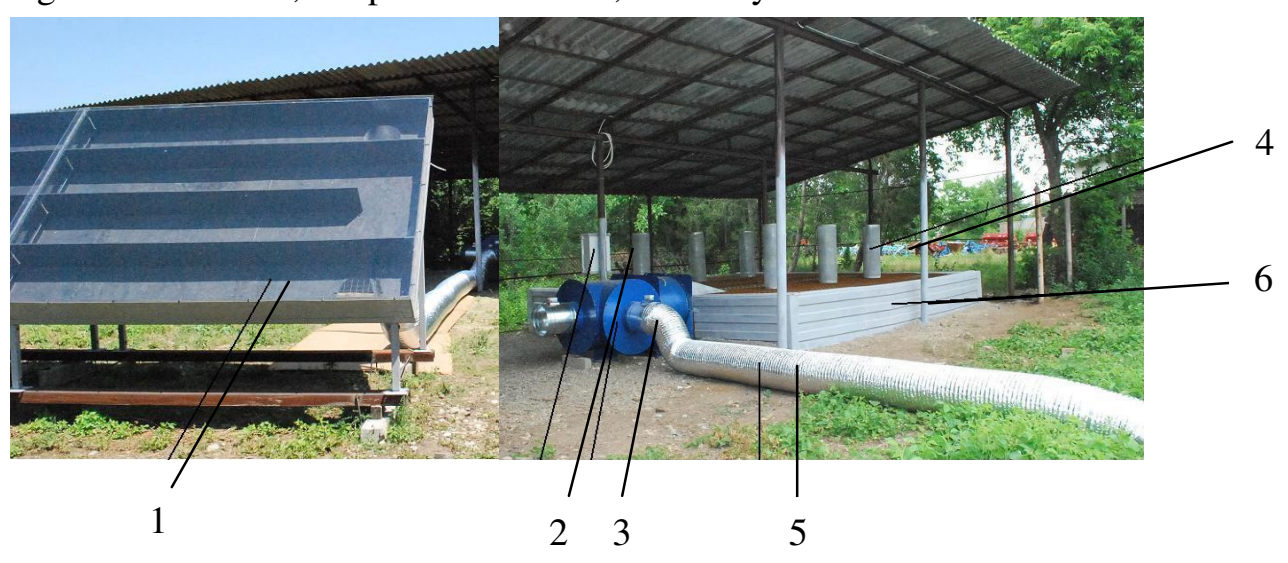

Fig. 2. Experimental model of installation for fodder ventilation: 1 - assembled solar panel;

2 - electrical installation; 3 - equipment for ventilation; 4 - ventilation tube placed in the fodder; 5 - hot air piping circuit; 6 - drying platform (uniformity room)

The drying agent used in this case was the air and the drying modes approached: natural drying, carried out in the open air and artificial drying, carried out with the help of the installation.

The study investigated the influence of the following parameters: the humidity of the fodder, the temperature and humidity of the aeration agent (characteristic of the environment) on the drying time of the feed through the aeration process using the IVF ventilation system.

Ventilation of deposited fodder can be done with atmospheric air at ambient or heated air in the solar panel provided by the IVF. The radiated sunlight is captured by the panel walls and transferred to the air in the panel. The heat transfer phenomenon occurs at the direct contact of the air with the construction elements of the panel. The heated air is directed to the drying platform through the hot air piping (Figure 2, Item 5) [9]. 
In the experiments the material used is the herbage forage grasses. In order to carry out the experimental tests with the IVF plant, the fodder plants were harvested on two experimental lots within I.N.M.A. Bucharest during two different periods [10], Table 1.

Table 1

Types of feed used in the tests of the experimental lots

\begin{tabular}{|c|c|c|c|c|}
\hline Characteristics & UM & $\begin{array}{c}\text { Fodder type 1 } \\
\text { (Period I) }\end{array}$ & $\begin{array}{c}\text { Fodder type 2 } \\
\text { (Period II) }\end{array}$ & Observation \\
\hline Type & - & hay from the meadow & shamrock & - \\
\hline $\begin{array}{c}\text { The amount of fodder } \\
\text { loaded on the platform }\end{array}$ & $\mathrm{kg}$ & 1800 & 3000 & - \\
\hline Harvest moisture & $\%$ & 55 & 74 & - \\
\hline Harvest time & - & May & June & - \\
\hline Drying period ground & days & 1 & 2 & $\begin{array}{c}\text { They were } \\
\text { carried out } \\
\text { successive turns } \\
\text { of furrows }\end{array}$ \\
\hline $\begin{array}{c}\text { Ground drying } \\
\text { of the fodder }\end{array}$ & hours & 24 & 45 & \\
\hline
\end{tabular}

The plant's technical equipment allows monitoring of the drying process by ventilation, as follows: measurement of weather parameters (temperature, humidity) with the agro-meteorological weather station type Delta-T Weather Stations-WS-STD1; measuring temperature in fodder with sensors $\mathrm{P}_{\mathrm{t}} 100$ placed in the fodder mass;monitoring the temperature in the fodderwith the Micro PLC Alpha + microcomputer on the control panel; ventilation control and control according to feed and environmental parameters is performed with the electrical installation, the control panel, the inlet flanges mounted on the hot air and cold air circuits controlled by the electric motors according to the ventilation program set at Micro PLC.

In order to determine feed humidity during the aeration process samples from 4 different areas of the platform loaded with fodder material (fodder plant or clover) subjected to ventilation were sampled to follow if the feed was uniform dried, Figure3.

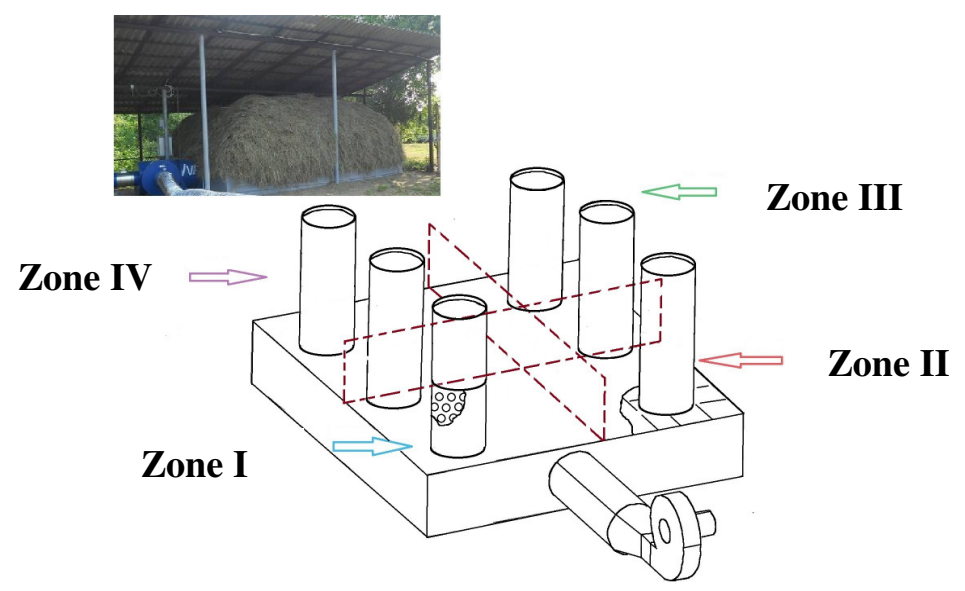

Fig. 3. Platform loaded during experimental researches with area division and highlighting of tube ventilation

Periods of experimentation have been differentiated by the following features:

- Period I, characterized by low atmospheric temperatures caused by rainy weather and high air humidity, the material subjected to the aeration process was composed of a mixture of fodder plants harvested from the meadow and in the amount of approx. $1800 \mathrm{~kg}$.

- Period II, characterized by high summer atmospheric temperatures and low air humidity, and the material subjected to the aeration process consists of clover fodder plants, harvested from another experimental lot, in the amount of approx. $3000 \mathrm{~kg}$. 
The drying process has been achieved by ventilating the feed mass stored on the platform. Depending on the harvest and preservation period of hay (spring, summer or autumn), as well as the weather conditions specific to the harvesting period (rainfall, temperature and humidity)a ventilation program with cold and / or hot air has been set up $[9 ; 10]$.

Drying of fodder plants stored on the platform begins, when the ventilation system is switched on (by actuating the electric panel start button) and the fan suction air (cold or heated / alternately cold and hot) is introduced through the intake channel in the uniform room, where it is diffused in the mass of the feed layer, according to the ventilation program. As long as the ventilation system, temperature sensors $P_{t} 100$, is operating, it measures the temperature inside the feed.

If the break between two ventilation intervals, the feed-in temperature increases to a value above $30{ }^{\circ} \mathrm{C}$, the electrical and control system, through the safety program set in the Micro PLS, controls the fan start-up, eliminating the danger of the feed being fed.

For the humidity of the hay, $200 \mathrm{~g}$ feed samples were taken daily, inserted into the Memmert UNE 200-800 oven, and held for 3 hours at $105^{\circ} \mathrm{C}$. They were removed from the oven and after cooling they were weighed and the moisture content was determined with the formula 1 from [5] p. 12.

$$
u_{f}=\frac{200-m_{p u}}{2} \text {, }
$$

where $u_{f}$-feed humidity, \%;

$m_{p u}$ - sample mass resulting from drying and cooling, g.

Drying is considered to be finished, when the internal temperature stabilizes at $18{ }^{\circ} \mathrm{C}$ and after an interruption of 12-24 hours there is no further heating of the feed.

\section{Results and discussion}

Installation for additional drying of the hay is intended to reduce the humidity of fodder stored in the hay, from humidity of $35-40 \%$ at humidity of approx. $18 \%$ by ventilation with cold or heated air for optimal long-term conservation and obtaining feeds of superior nutritional quality.

\section{Interpretation of the results obtained during the first period of the experimental research}

Experimental research for the analysed period ranged over 11 days, totalling 50 hours of ventilation of material deposited on the plant platform. As rainfall and atmospheric humidity were recorded in May of this year, it was taken into account that within one day the measurements were at two hours between 7.30 and 15.30 , monitoring required by daily rainfall.

Interpretation of the graphical results indicates the variation in temperature and humidity of atmospheric air used as a drying agent, Figures 4 and 5.

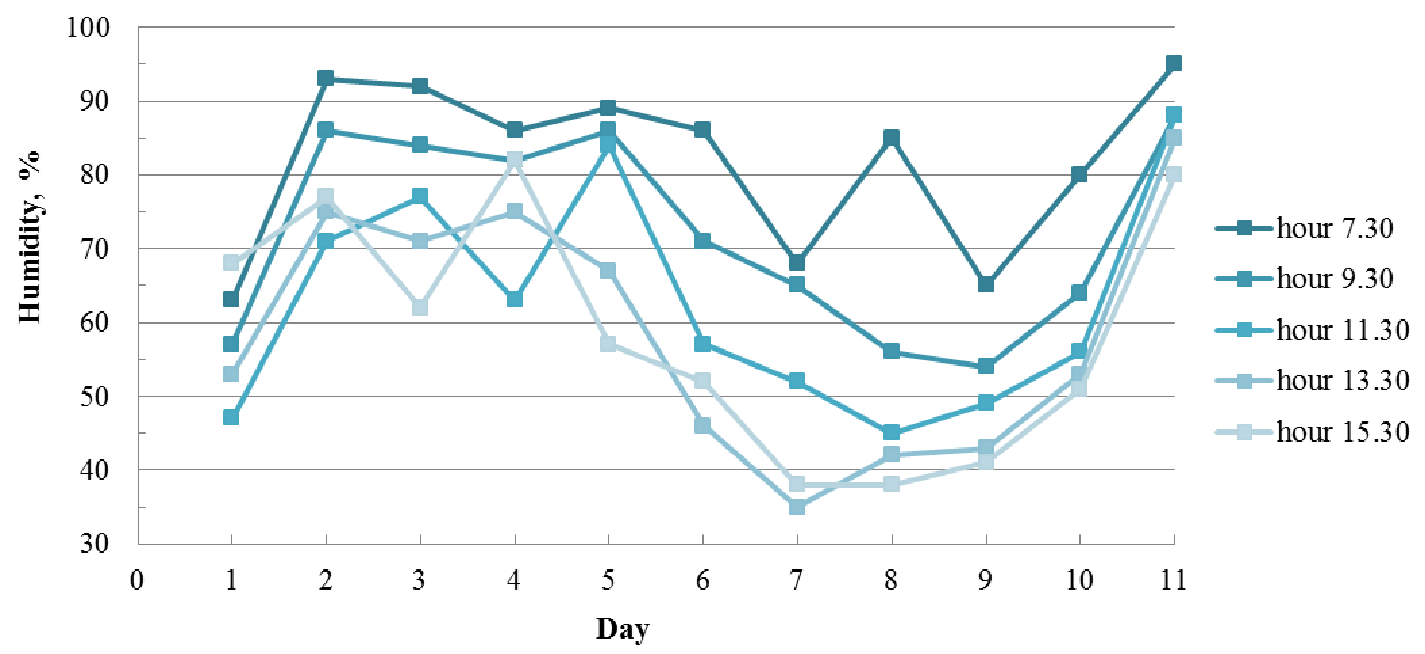

Fig. 4. Variation of humidity in atmosphere during process of aeration, at specific times of the day 
From the graph of the variation of air humidity it is observed that between 7:30 and 9:30 there were recorded maximum values between $85-95 \%$, Figure 4, during or after raining. In those moments, ventilation was performed only for 30 minutes in order to avoid the increase in the temperature of the feed and its degradation, Figure 6, zones $I$ and $I I$.

Analysing the variation of the two parameters, the humidity and the air temperature, (Figures 4 and 5) their evolution is inversely proportional and fluctuating from day to day. In these conditions it was ventilated according to the methodology in the interval of 13:00-16:00.

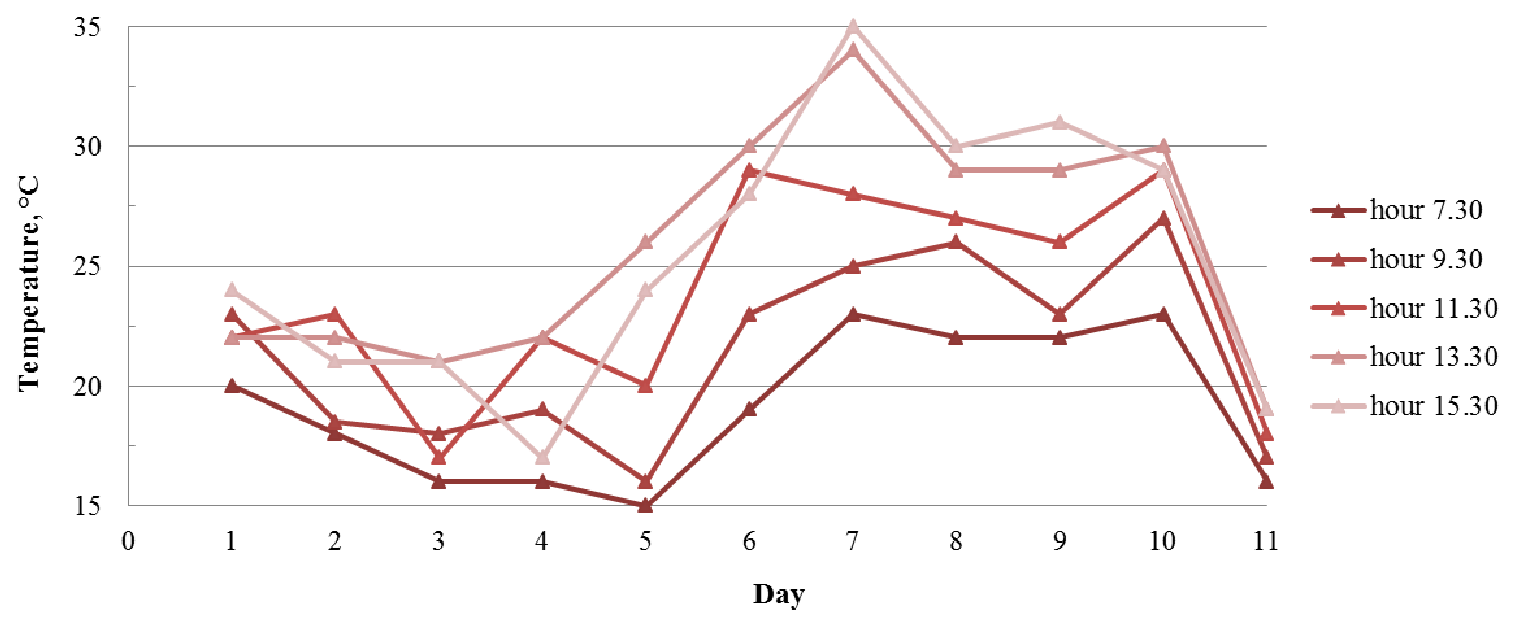

Fig. 5. Variation of atmospheric air temperature during process of aeration, at established time intervals of the day

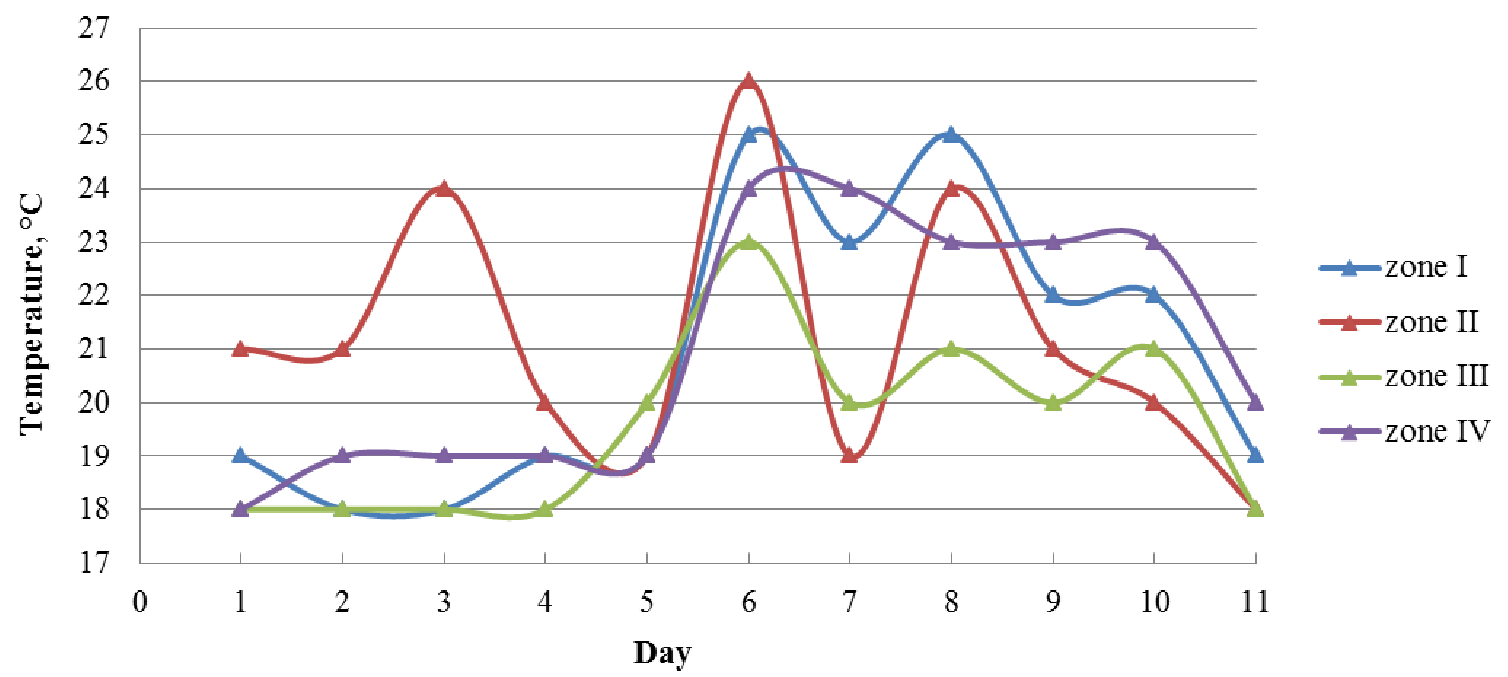

Fig. 6. Temperature variation in fodder mass during aeration process, in 4 zones of platform

The conduct of the aeration process of the feed in the climatic conditions recorded during the studied period influenced the duration of the aeration process, the decrease of the feed humidity below $18 \%$ was made in approx.50 hours of ventilation, respectively 11 days, Figure 7.

It is known from the literature that under these drying conditions the stored feed would have deteriorated significantly, if it was not supposed through the ventilation process.

After analyzing and correlating the data from the two graphs (Figures 4 and 5) it is observed that the atmospheric parameters influence the decreasing evolution of the humidity values in the fodder mass, (Figure 7), in all four areas. 


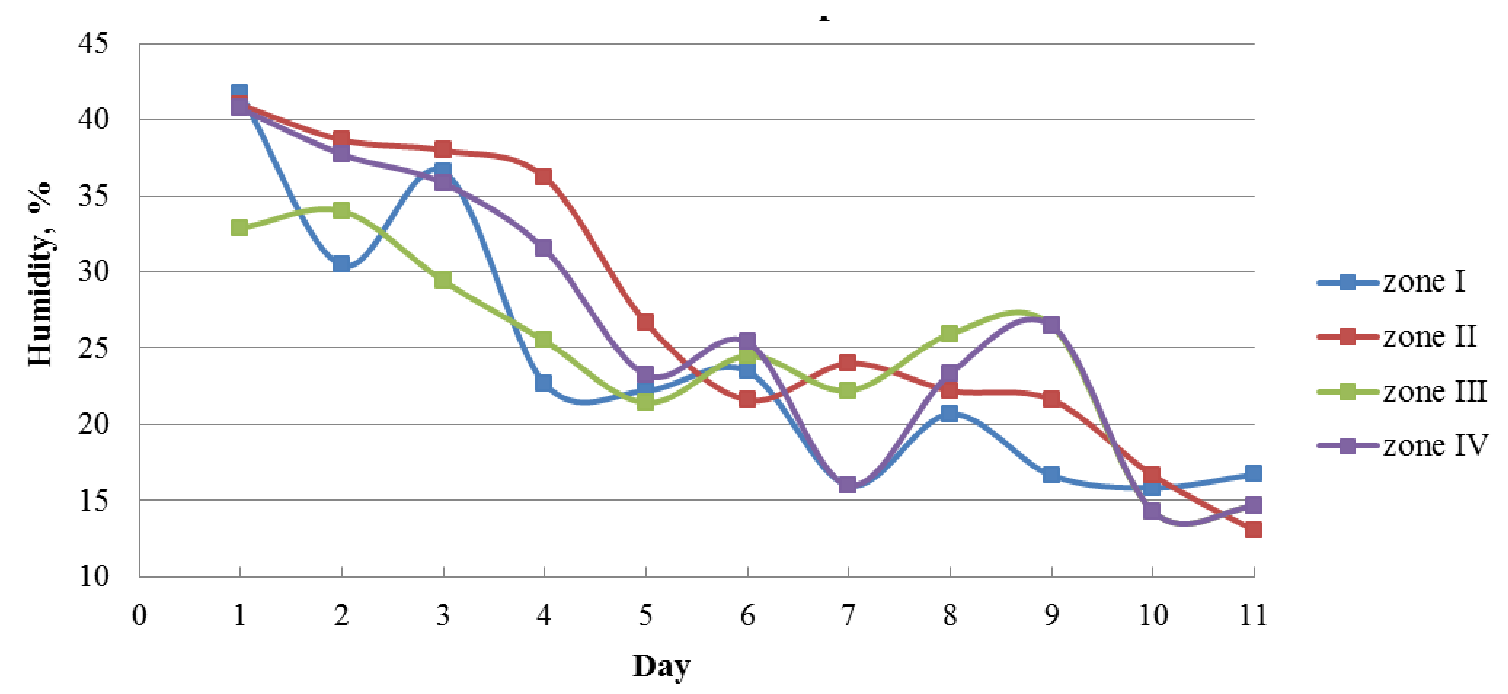

Fig. 7. Humidity variation of stored material during aeration process, in 4 zones of platform

\section{Interpretation of the results obtained during the second period of the experimental research}

During this period of the experimental research the influence of atmospheric conditions on the studied process is studied in the case of the material placed on the drying platform being from clover. Knowing from the literature that clover is a leguminous plant, it contains more nutritive substance but also a relatively high humidity content.

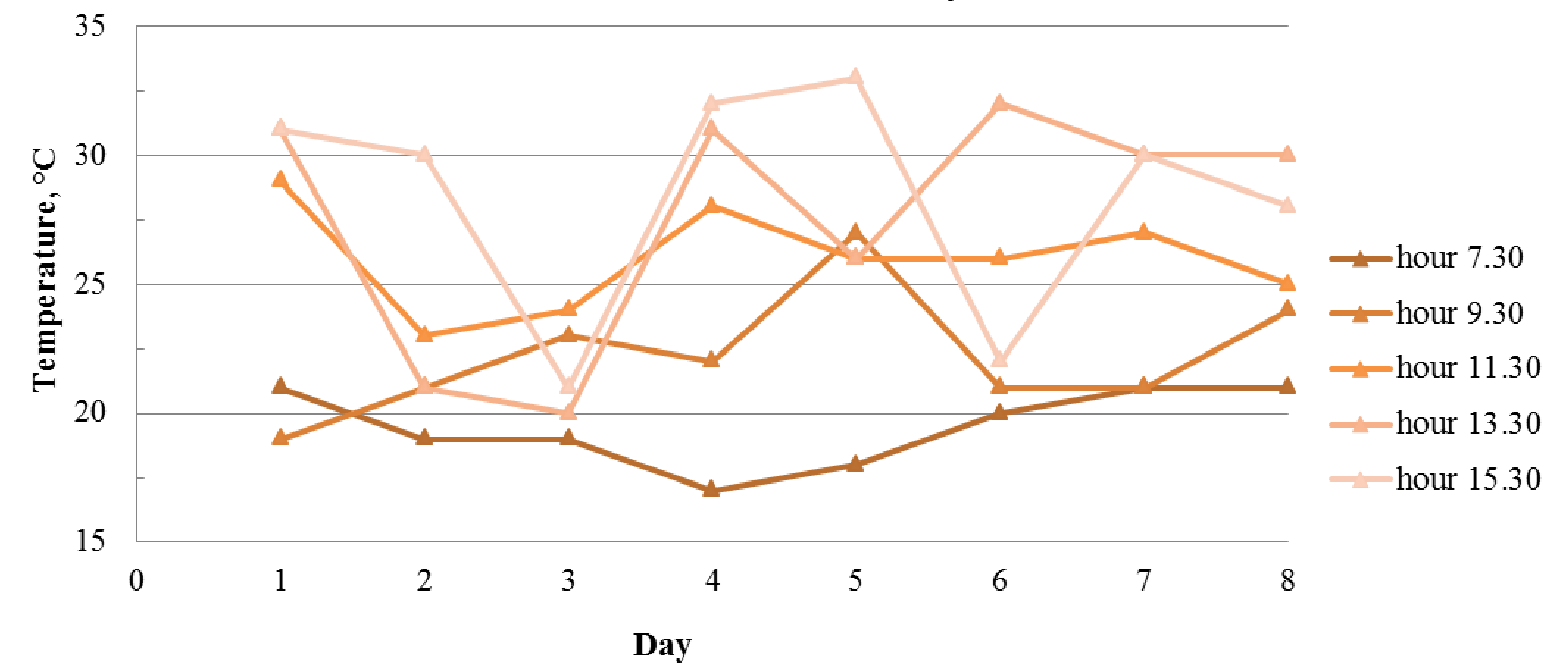

Fig. 8. Variation of temperature of aeration agent during the process, at various times of the day

The charts in Figure 8 highlight high temperatures throughout the day, characterized by a warm weather, but with a high humidity in the morning, 7: 30-9: 30, Figure 9.

It is noted that the temperature variation recorded in the material reaches some warning points on the material hardening in zone I on days 5 and 7 and in zone III during the first 4 days of ventilation the temperature is kept at values that could damage the quality of the fodder, Figure 10.

These high values, which exceed the average of $30^{\circ} \mathrm{C}$ in feed, are reflected in maintaining the initial moisture of the deposited material in zone III during the first days of the aeration drying process, even with a slight increase trend of 33.28-36.75\%, Figure 11.

Zone I performs the best drying process by loss of feed humidity, while the most spectacular decrease in humidity is recorded in zone IV of the platform, about $40 \%$ loss of moisture over the same period, 8 days. 


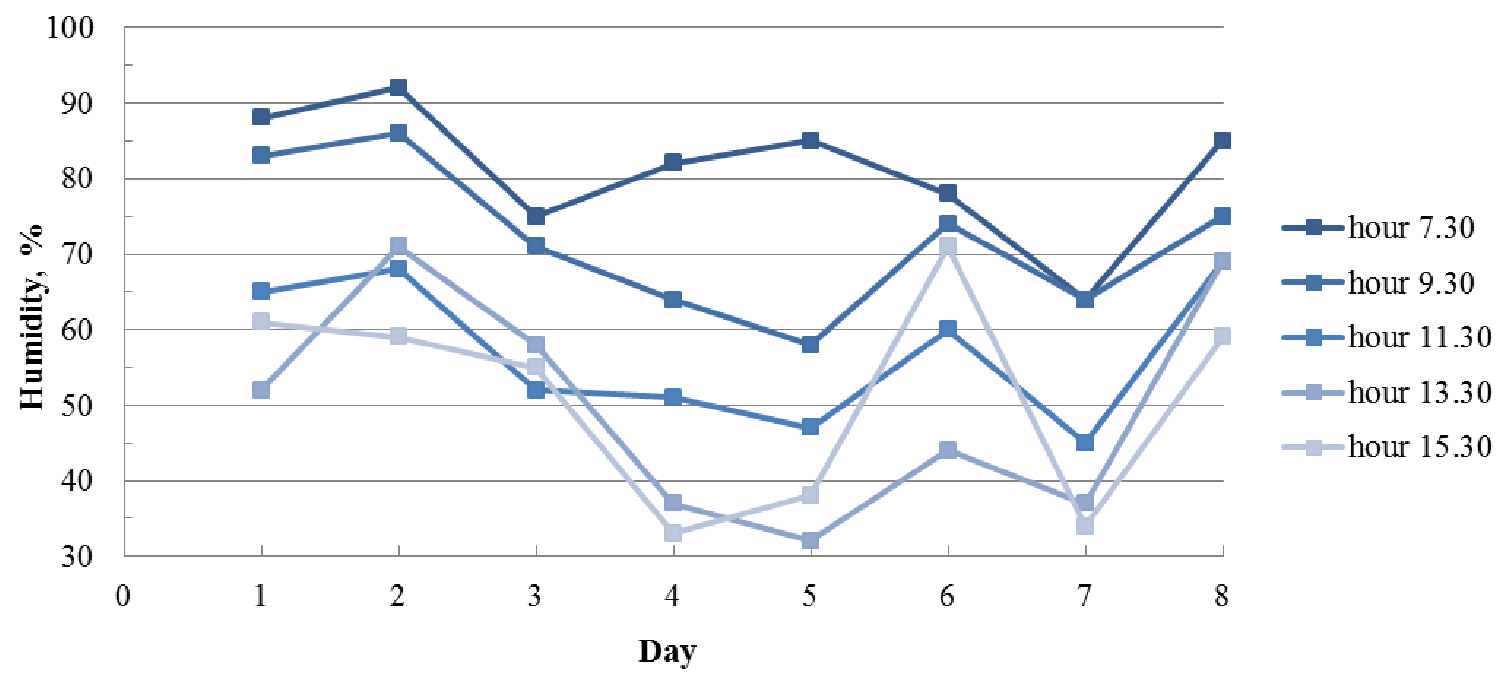

Fig. 9. Variation of humidity of aeration agent during the process of aeration of clover fodder, at various time intervals of the day

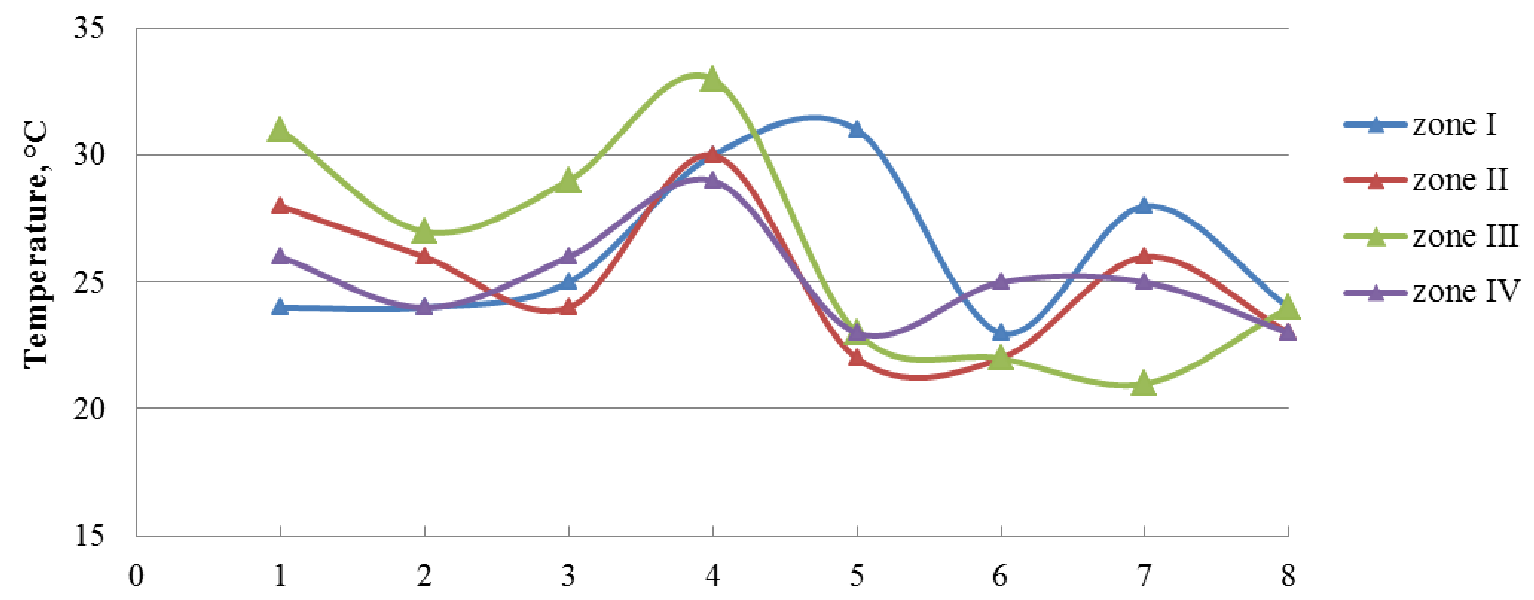

Day

Fig. 10. Variation of temperature of deposited material (clover) during the process of aeration in different areas of platform

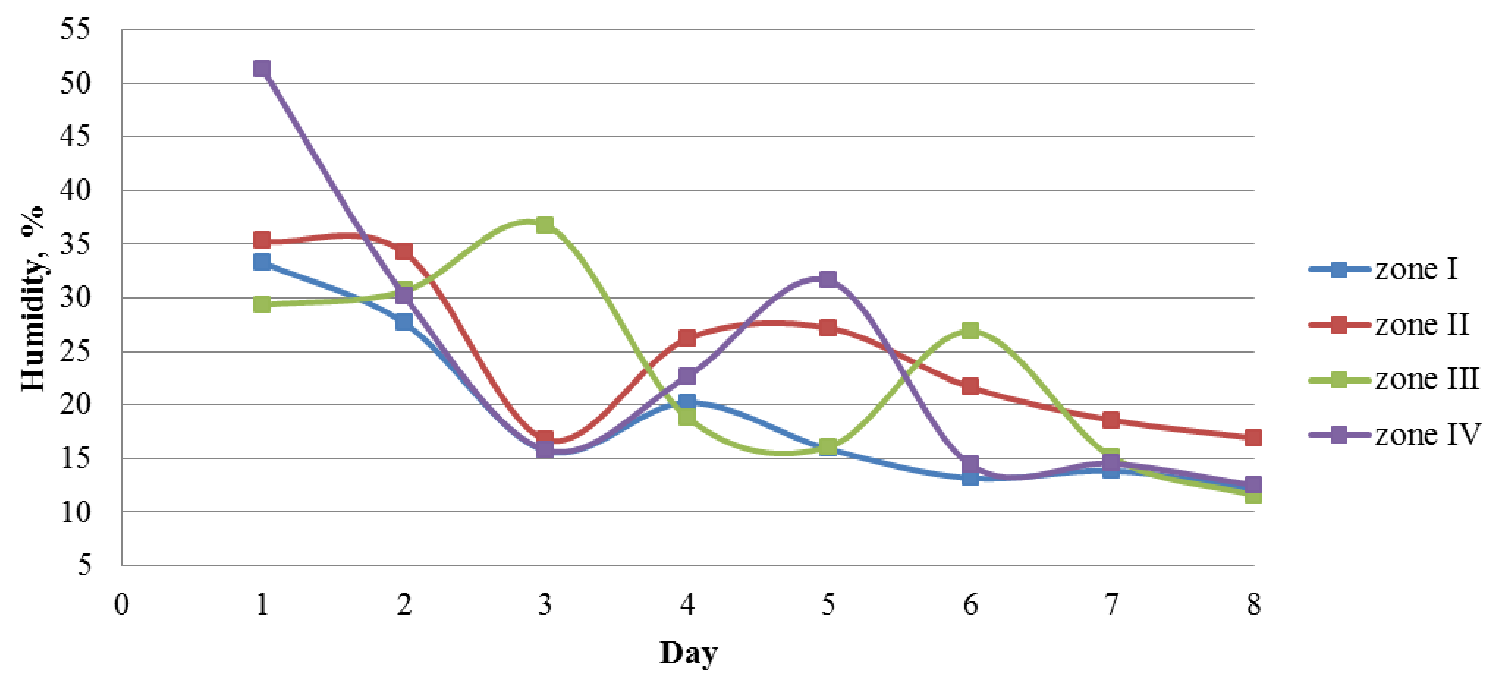

Fig. 11. Variation of humidity of deposited clover during the process of aeration in different areas of platform 


\section{Conclusions}

1. The harvesting, preparation and preservation of fodder by drying or silage technologies are primarily aimed at providing quality food throughout the year to livestock in zoo technical farms.

2. Since hay production is considered to be the most cost-effective method for preserving dry-forage plants, the technology has been studied to determine the drying of fodder by ventilation.

3. In order to reduce the qualitative and quantitative losses due to the long-term exposure to atmospheric factors during drying on stubble of feed post-harvesting, research has been carried out, which has led to installation for ventilating the bulk fan with cold air or heated in assembled solar collectors.

4. The proposed technology for reducing nutrient losses in traditional stubble drying is characterized by the storage of herbage forage at humidity of $35-45 \%$ and the completion of drying by ventilation with cold and / or warm air until the humidity of the feed is below $18 \%$,

5. The experiments were carried out in two time periods, with different characteristics. The results demonstrated the influence of meteorological conditions, temperature and air humidity on the aeration process.

6. The weather conditions of the two periods varied first in rainy weather and second in warm weather, as a result, the duration of the aeration process until the drying of the two types of fodder in the period I was increased by 3 days, even if the material undergoing the second drying process was clover.

7. Analysing the evolution of the humidity in the feed mass over time, it was found that during the drying process (influenced by air temperature and humidity), conservative moisture (below $18 \%$ ) was progressively reached in all four areas, even though the determined values are not identical.

8. The different final values for humidity (max. $2.5 \%$ ) and temperature may be due to several factors: sample samples taken from areas I ... IV were not extracted from the same site; the tamper sensors in each area were positioned in different locations, the feed storage was a roof-only construction and the weather conditions (rain, sun) had a stronger influence on the feed material than the platform platforms, the feed density on the platform was not uniform, in some places being pressed by infusing the uniformity of aeration.

9. Gathering of hay with a dry substance content of 60-70\% and drying up to an $18 \%$ consistency humidity with the cold and / or warm air ventilation system shortens the drying time, reducing the nutrient losses by repeated handling and obtaining high quality feed.

\section{References}

[1] Frederiksen H, Dănuţ D., Maşinistru M., Greculescu A. Sisteme pentru depozitarea furajelor. Standarde de fermă (Fodder storage systems. Standard company). Danish Agricultural Advisory Service. Manual elaborated within the Project "Modernizarea Sistemului de Informare şi Cunoaştere în Agricultură” (MAKIS), 2010.

[2] Maciuc V. , Leonte C., Radu-Rusu R.Manual de bune practici in cresterea bovinelor (Manual of good practices in cattle breeding).Publishing House ALFA, 2015, Iasi, pp. 8-14.

[3] Coleman S. W., Moore J. E.Feed quality and animal performance.Field Crops Research, Volume 84, Issues 1-2, Elsevier, 2003, pp. 17-29.

[4] Popa O., Milos M., Bunicelu El., Alimentatia animalelor domestice (Nutrition of Domestic animal),Publishing House Didactica si Pedagogica, 1980.

[5] Hermenean I., Mocanu V. Tehnologii, maşini şi instalaţii pentru recoltarea şi conservarea sub formă de fân a furajelor de pe pajiști (Technologies, machinery and plants for harvesting and preserving hay fodder from meadows). Publishing House Universitatea Transilvania din Braşov, Romania, 2008.

[6] Horrocks R.D., Vallentine J.F.Processing and Storing Hay, Harvested Forages. Elsevier, 1999.

[7] Voicu E., Gângu V., Ciurel G., Tican N. Machine for Green Fodder Ensiling in Bag Polyethylene. INMATEH, vol. 23, No. 5, 2007, Bucharest, Romania, pp. 33-39.

[8] Mănişor P. Tehnologii şi utilaje pentru producerea şi valorificarea furajelor (Technologys and equipments for the production and valoration of fodder),1981, Bucharest, Romania.

[9] Mănişor P. Mecanizarea şi automatizarea lucrărilor în zootehnie (Mechanization and automation of works in animal husbandry).Publishing House CERES, 1994, Bucharest, Romania. 
[10] Nedelcu A., Popa L., Ciupercă R. Cercetări realizate cu instalaţia pentru uscarea fânului prin ventilare cu aer rece sau cald - IVF (Researchs realized with the ventilation system for drying hay with cold or warm air - IVF). The Bulletin AGIR, Year XIX, no.2, Romania, 2014, pp. 57-62.

[11]Zaica A., Nedelcu A, Ciupercă R., Popa L., Zaica Al., Sorică C. Studiul pierderii de umiditate a furajului sub influenta agentului de aerare (Study of the loss of humidity content to fodder under the influence the agent of aeration). ISB-INMA Teh 2016 international symposium, agricultural and mechanical engineering, October 27-29, 2016, I.N.M.A. Bucharest, Romania, pp. 723-730. 